\title{
AEROMAGNETIC MAP OF CENTRAL IOWA
}

By

John R. Henderson and Joseph L. Vargo

GEOPHYSICAL INVESTIGATIONS

MAP GP-476

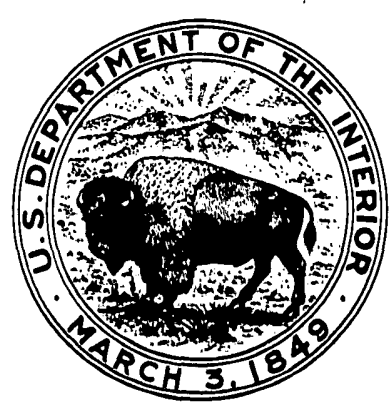

